\title{
Chromosome numbers and polyploidy events in Korean non-commelinids monocots: A contribution to plant systematics
}

\author{
Tae-Soo JANG* and Hanna WEISS-SCHNEEWEISS ${ }^{1}$ \\ Department of Biological Science, College of Bioscience and Biotechnology, Chungnam National University, Daejeon 34134, Korea \\ ${ }^{1}$ Department of Botany and Biodiversity Research, University of Vienna, A-1030 Vienna, Austria
}

(Received 4 June 2018; Revised 9 September 2018; Accepted 16 December 2018)

\begin{abstract}
The evolution of chromosome numbers and the karyotype structure is a prominent feature of plant genomes contributing to or at least accompanying plant diversification and eventually leading to speciation. Polyploidy, the multiplication of whole chromosome sets, is widespread and ploidy-level variation is frequent at all taxonomic levels, including species and populations, in angiosperms. Analyses of chromosome numbers and ploidy levels of 252 taxa of Korean non-commelinid monocots indicated that diploids (ca. 44\%) and tetraploids (ca. 14\%) prevail, with fewer triploids (ca. 6\%), pentaploids (ca. 2\%), and hexaploids (ca. 4\%) being found. The range of genome sizes of the analyzed taxa $(0.3-44.5 \mathrm{pg} / 1 \mathrm{C})$ falls well within that reported in the Plant DNA C-values database (0.061-152.33 pg/1C). Analyses of karyotype features in angiosperm often involve, in addition to chromosome numbers and genome sizes, mapping of selected repetitive DNAs in chromosomes. All of these data when interpreted in a phylogenetic context allow for the addressing of evolutionary questions concerning the large-scale evolution of the genomes as well as the evolution of individual repeat types, especially ribosomal DNAs (5S and $35 \mathrm{~S}$ rDNAs), and other tandem and dispersed repeats that can be identified in any plant genome at a relatively low cost using next-generation sequencing technologies. The present work investigates chromosome numbers $(n$ or $2 n$ ), base chromosome numbers $(x)$, ploidy levels, rDNA loci numbers, and genome size data to gain insight into the incidence, evolution and significance of polyploidy in Korean monocots.
\end{abstract}

Keywords: base chromosome number, chromosome number, ploidy level, FISH, hybridization, polyploidization

Chromosome numbers and karyotype structure have always been considered to be an important character in analyses of the phylogenetic relationships and evolutionary processes in angiosperms (Levin and Wilson, 1976; Guerra, 2008; Jang et al., 2013). To date, chromosome numbers have been reported for about $25-30 \%$ of flowering plants (Bennett, 1998; WeissSchneeweiss and Schneeweiss, 2013). The chromosome numbers in angiosperms vary 160-fold (Weiss-Schneeweiss and Schneeweiss, 2013) ranging from $2 n=4$ (Poaceae, Hyacinthaceae, Asteraceae, Cyperaceae: Vanzela et al., 1996; Roberto, 2005) to $2 n=640$ (Crassulaceae: Uhl, 1978). The haploid chromosome numbers of the majority of angiosperms range between $n=7$ and $n=20$ (Grant, 1982; Masterson, 1994). Taxonomic groups display varying degrees of chromosome number changes both among and within genera (e.g., $2 n=8,10,12,14,19,20,25,26,27,28,35,42$ in Prospero/Hyacinthaceae: Jang, 2013; $2 n=18,20,22,24,28$, 36, 40, 46, 48, 54, 56, 60, 66 in Melampodium/Asteraceae: Stuessy, 1971; Weiss-Schneeweiss et al., 2009; $2 n=24$ in Lilium/Liliaceae: Sultana et al., 2010), and such changes continue to be used in systematics and elucidating evolutionary patterns within these groups of plants (Mayrose et al., 2010; Schubert and Lysak, 2011; Husband et al., 2013; McCann et al., 2016).

Hybridization and polyploidization have been commonly observed in many economically important plant groups (Lim et al., 2007; Mandáková et al., 2013), but recent studies have demonstrated that these processes have also been a major force

\footnotetext{
*Author for correspondence: jangts@cnu.ac.kr
} 
in the diversification and speciation of angiosperms in general (Leitch and Leitch, 2008). Hybrids and polyploids experience numerous chromosomal rearrangements (e.g., inversions, deletions, translocations, centromeric shifts, etc.) and more subtle changes in sequence composition (sequence loss or gain, expansion/reduction of repetitive DNA), and they continue to generate species diversity contributing to speciation events (Soltis and Soltis, 2009; Weiss-Schneeweiss and Schneeweiss, 2013). The propensity for polyploidization appears to be unequally distributed in plant groups with polyploidy in angiosperms being more common in monocots (ca. 58\%) than in dicots (ca. 43\%) (Soltis and Soltis, 2009; Weiss-Schneeweiss et al., 2013).

There are two general types of polyploidy: autopolyploidy (i.e., multiplication of chromosome sets within a single species or genome) and allopolyploidy (i.e., multiplication of chromosome sets accompanied by merger of genomes of two or more species), both of which arise as a result of a failure of either meiotic or mitotic cell division (Stebbins, 1971; Otto and Whitton, 2000; Ramsey and Schemske, 2002). Although autopolyploidy has historically been considered as less frequent and less important than allopolyploidy (Stebbins, 1971; Soltis et al., 2007), natural autopolyploids are much more common than originally assumed (Ramsey and Schemske, 2002; Parisod et al., 2010), as recent studies continue to demonstrate. Multiple ploidy levels have been demonstrated to exist within many species (autopolyploidy), which often influences the degree of morphological variation in those taxa. Current focus of polyploidy research is on the genetic, epigenetic, chromosomal, and genomic consequences of polyploidization (Bowers et al., 2003; Liu and Wendel, 2003; Osborn et al., 2003; Rapp and Wendel, 2005), mechanisms of polyploid formation and establishment (Ramsey and Schemske, 2002), the ecological effects of polyploidization (Weiss-Schneeweiss et al., 2013; Soltis et al., 2016), and most of all, the impact of polyploidy on plant diversity (Mandáková et al., 2017; Jang et al., 2018).

Modern cytology greatly profits from technical advances especially in situ hybridization (e.g., fluorescence in situ hybridization [FISH] and genomic in situ hybridization [GISH], respectively), large scale screening for polyploidy incidence using flow cytometry, and the advent of nextgeneration sequencing (NGS) technologies. These allow identification, quantification and localization on the genomes of various repeat types, which contribute to genome size variation and changes of which accompany species diversification and speciation (Weiss-Schneeweiss et al., 2015). Repetitive DNA fraction in plant genomes comprises tandem repeats (e.g., satellite DNAs, microsatellites, and ribosomal RNA genes [5S and 35S rRNA genes]) and dispersed repeats represented by mobile genetic elements (Weiss-Schneeweiss et al., 2015). The localization and evolution of tandemly repeated genes encoding 35S (18S-5.8S-25S) and 5S rRNAs in plants have been particularly useful for analysing systematic relationships between closely related species (WeissSchneeweiss and Schneeweiss, 2013).

The chromosome numbers in Korean non-Commelinids monocots have previously been reported for a number of taxonomically closely related taxa (Rice et al., 2015, references therein), although the incidence of polyploids and its evolutionary aspects have not been addressed in detail. It is therefore timely to summarize the knowledge of chromosome numbers, genome sizes, and polyploidy incidence in the Korean monocots (Rice et al., 2015; Vitales et al., 2017) and to identify the most important taxonomic groups in which questions of chromosomal evolution can be addressed most effectively.

\section{Chromosome numbers and the incidence of polyploidy in non-commelinids monocot species native to Korea}

All available chromosome numbers and base chromosome numbers for Korean non-Commelinids monocots were obtained from the Chromosome Counts Database (CCDB, version 1.45; http://ccdb.tau.ac.il/Angiosperms/, accessed on 2018 May 22) (Rice et al., 2015) following APG IV classification system (Angiosperm Phylogeny Group IV) (Appendix 1) (The Angiosperm Phylogeny Group, 2016). Due to the scarcity of available data on chromosome numbers and ploidy levels variation in Korean Commelinids including Arecales, Commelinales, Poales, and Zingiberales (The Angiosperm Phylogeny Group, 2016), these were excluded from the current analyses.

The systematic ranking of taxa adopted in this study was mainly based on the recent online resources for monocot plants (http://emonocot.org/), the World Checklist of Selected Plant Families (http://wcsp.science.kew.org), the Missouri Botanical Garden Tropicos Database (http://www.tropicos.org), and the nomenclature was adopted from the most accepted taxonomic treatment for the species based on the Korean Plant Names Index Committee (http://www.nature.go.kr/kpni/index.do) (Appendix 1).

The genome size values and ploidy level inferences in Korean non-Commelinids monocots were retrieved from the Plant DNA C-values database (http://www.kew.org/cvalues/, accessed on 2018 May 22) (Bennett and Leitch, 2012). The 
data on number and chromosomal localization of rDNA loci (5S and 35S rDNA) in Korean non-Commelinids monocots obtained applying fluorescent in situ hybridization were retrieved from the third release of the plant rDNA database (Vitales et al., 2017; http://www.plantrdnadatabase.com/, accessed on 2018 May 22).

Chromosome numbers are reported for 252 taxa (232 species, 2 subspecies, and 18 varieties) of Korean monocots, with the exception of Commelinids, due to the scarcity of published chromosome numbers for this very speciose this group (Appendix 1). Base chromosome numbers and ploidy levels variation is given for each taxon in Appendix 1. The chromosome numbers reported for Korean non-Commelinids monocots vary between $2 n=2 x=10$ in Paris verticillata M. Bieb. and $2 n=40 x=400$ in Dioscorea japonica Thunb. (Appendix 1). To date, the documented chromosome numbers in angiosperms vary from $2 n=4$ (e.g., Ornithogalum tenuifolium Delaroche in Hyacinthaceae) to $2 n=640$ (Sedum suaveolens Kimnach in Crassulaceae), although most species possess between $2 n=14$ and $2 n=40$ chromosomes (Guerra, 2008; Weiss-Schneeweiss and Schneeweiss, 2013). The base chromosome numbers of analyzed Korean species vary from $x=5$ in the genus Paris L. to $x=30$ in the genus Hosta Tratt. (Appendix 1). Not only interspecific base chromosome number variation is found in thirteen genera analyzed here (Acorus L., Arisaema Mart., Alisma L., Hydrocharis L., Potamogeton L., Lycoris Herb., Asparagus Tourn. ex L., Polygonatum Mill., Scilla L., Iris Tourn. ex L., Cephalanthera Rich., Gastrodia R. Br., Fritillaria Tourn. ex L.) (Appendix 1) but also intraspecific base chromosome number variation is found within several species $(x=9,11$, 12 in Acorus calmus L.; $x=13,14$ in Arisaema amurense Maxim.; $x=13,14$ in Arisaema peninsulae Nakai; $x=13$, 14 in most of taxa in the genus Potamogeton L.; $x=9,10$ in Polygonatum falcatum A. Gray; $x=10,11$ in Polygonatum humile Fisch. ex Maxim.; $x=9,10,11$ in Polygonatum involucratum (Franch. \& Sav.) Maxim.; $x=8,9$ in Scilla scilloides (Lindl.) Druce) (Appendix 1). The incidence of both interspecific ( $x=5,6,7$ in Lotus/Fabaceae: Grant, 1991; $x$ $=9,10,11,12,13,14$ in Melampodium/Asteraceae: Blöch et al., 2009; $x=3,4,5,6$ in Crepis/Asteraceae: Babcock and Jenkins, 1943) and intraspecific base chromosome number variation ( $x=5,6$, 7: Prospero autumnale complex: Jang et al., 2013; $x=8$, 9: Scilla scilloides complex: Choi et al., 2008) have quite frequently been reported in angiosperms (Husband et al., 2003). Due to very low levels of phenotypic variation and thus lack of diagnostic morphological characters for species delimitations in some taxonomically intricate plant groups (often treated as species complexes), more detailed karyological investigations of the chromosome number variations and karyotype structure are needed for correct interpretation of taxonomic and evolutionary patters as well as classifications of angiosperms in general, but also specifically of monocot species native in Korea in global world-wide context.

Two general types of polyploids can be distinguished, autopolyploids and allopolyploids. Allopolyploids originate via hybridization of at least two different taxa, thus carrying different multiplied sets of chromosomes, while autopolyploids result from multiplication of entire chromosome sets within one taxon, typically species. Thus, both hybridization and polyploidization may play an important role in creating new species diversity in angiosperms (Guerra, 2008; Soltis and Soltis, 2009; Husband et al., 2013; Weiss-Schneeweiss and Schneeweiss, 2013). In this study, the incidence of polyploidy has frequently been reported in Araceae Juss., Hydrocharitaceae Juss, Juncaginaceae Rich., Amaryllidaceae J. St.-Hil., Asparagaceae Juss., Dioscoreaceae R. Br., Liliaceae Juss., Melanthiaceae Batsch ex Borkh., Smilacaceae Vent. (Appendix 1). Analyses of ploidy levels distribution among these groups indicated that diploids (ca. 44\%) and tetraploids (ca. 14\%) prevail, with triploids (ca. 6\%), pentaploids (ca. $2 \%$ ), and hexaploids (ca. 4\%) being found less frequently (Fig. 1, Appendix 1). Polyploidy is less frequent in Orchidaceae than in other families of Korean nonCommelinids monocots (Appendix 1), in agreement with previous reports for this region (Goldblatt, 1980; Ko et al., 2009; Rice et al., 2015, references therein). Despite the relatively high incidence of polyploidy in Korean nonCommelinids monocot flora and ease of inferring more recent polyploidy events based purely on increase of chromosome numbers, the clear inference of the mode of polyploids origin and inferences of the patterns of their post-polyploidization genome evolution are non-trivial and thus are not attempted here. These require rigorous phylogenetic analyses of the genera harboring polyploids to infer putative parental species and subsequent molecular cytogenetic analyses as well as genome size measurements to infer the patterns of their genome evolution. Such data are available only for a handful of selected monocot taxa (Appendix 1) and thus, more indepth and group-oriented molecular cytological analyses are required to assist and guide species delimitation and interpretation of phylogenetic relationships and evolutionary patterns among Korean monocots (Choi et al., 2008; Jang et al., 2013; Jang and Weiss-Schnneeweiss, 2015). 


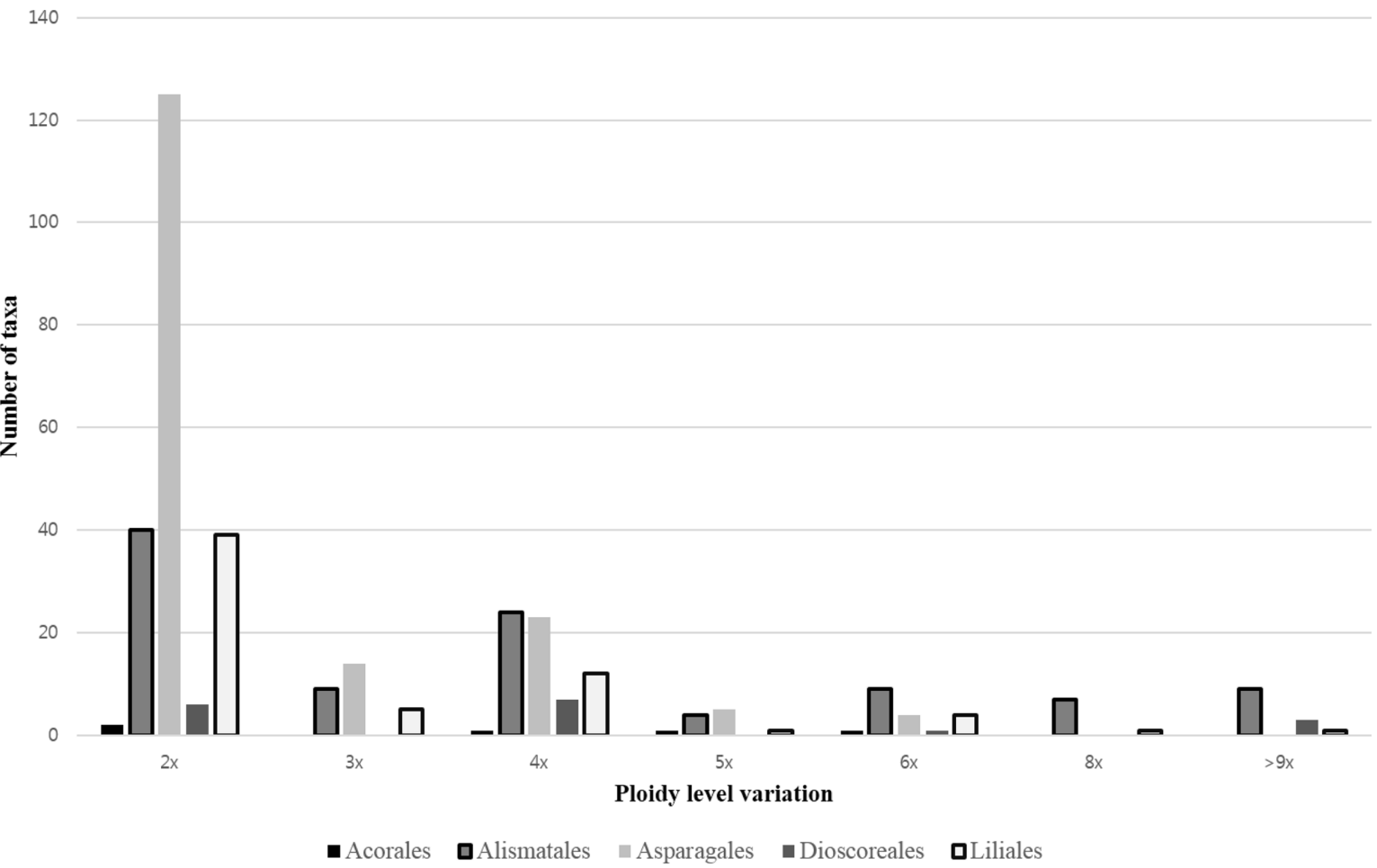

Fig. 1. Distribution of ploidy level variation containing two to eight ploidy levels in non-Commelinids monocot species occurring in Korea (representing their worldwide distribution).

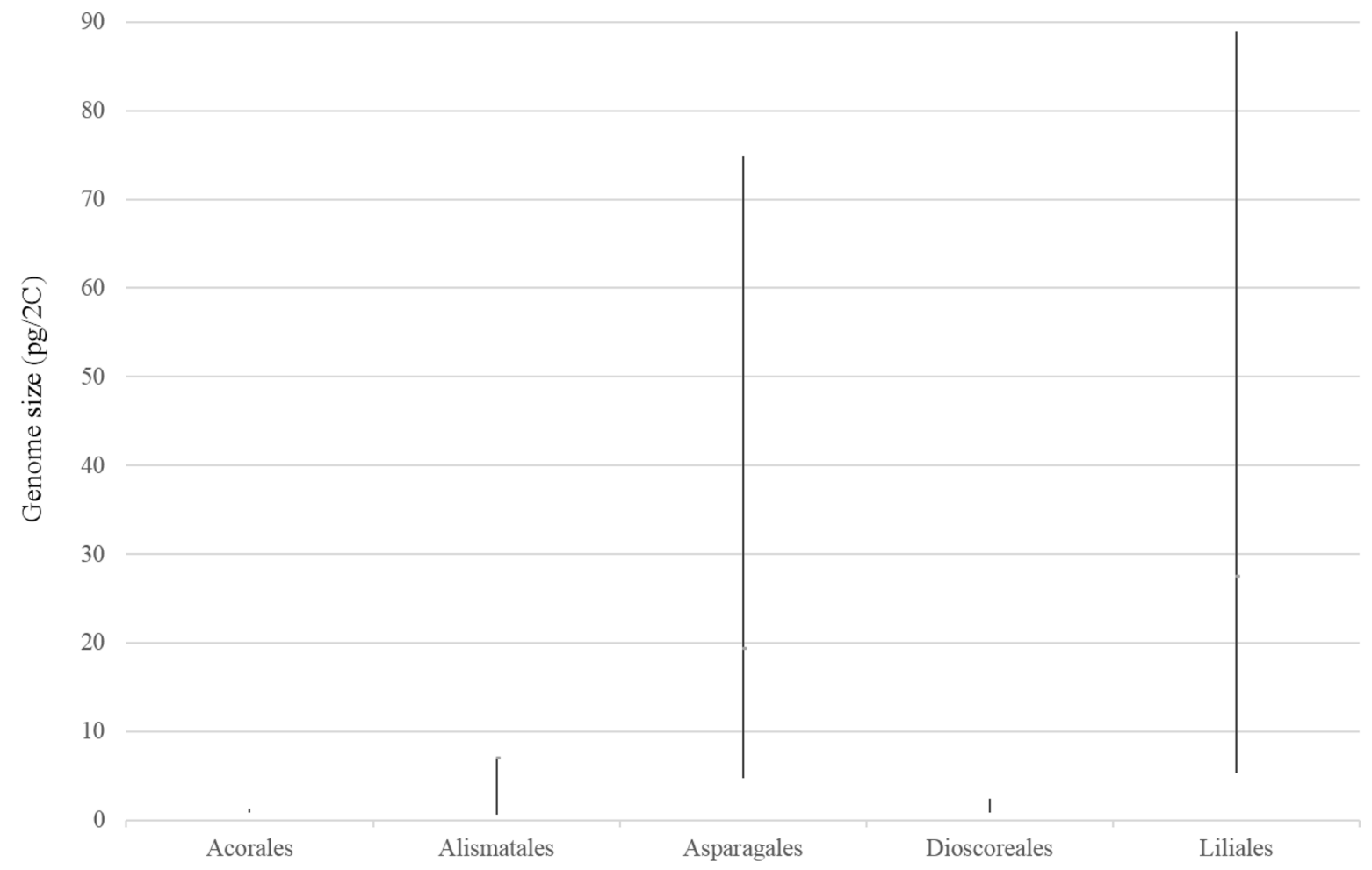

Fig. 2. Distribution of genome size variation in non-Commelinids monocot species occurring in Korea (representing their worldwide distribution). 


\section{Genome size variation in non-commelinids monocots species native to Korea (in worldwide context)}

The dynamics of genome size variation in a group of related diploid taxa can be very high despite lack of change in chromosome number. Genome size increase is, however, directly correlated to polyploidization, particularly recent one. Genome size changes in the absence of chromosome number changes are attributed to differential accumulation of various types of repetitive DNA elements (Leitch and Leitch, 2013). The range of genome sizes of Korean monocots falls within that reported in the Plant DNA C-values database which ranges from $0.061 \mathrm{pg} /$ 1C of DNA in Genlisea tuberosa Rivadavia, Gonella \& A. Fleischm. (Fleischmann et al., 2014) to $152.33 \mathrm{pg} / 1 \mathrm{C}$ of DNA in Paris japonica Franch. (Pellicer et al., 2010). The 1C-values of species studied here differ nearly 150 -fold and range from $0.3 \mathrm{pg}$ in Spirodela polyrrhiza (L.) Schleid. (Araceae) to 44.5 pg in Trillium kamtschaticum Pall. ex Pursh (Melanthiaceae) (Fig. 2, Appendix 1). In general, the broad range of variation of genome sizes in flowering plants correlates with the differences of total karyotype length and incidence of polyploidy, but also correlates with other factors, like the life cycle types (annual/ perennial) (Bennett, 1972; Chumová et al., 2015).

\section{Patterns of genome evolution: the use of molecular cytogenetics and phylogenetic analyses in Plant Systematics}

Extensive studies of chromosome numbers (including polyploidy incidence) and genome sizes in evolutionary context, aiming to elucidate the genome dynamics and often aiding taxonomic classifications have often been carried out in plants of agricultural importance or in model plants (Gong et al., 2012; Renny-Byfield et al., 2013; Novák et al., 2014; Zhang et al., 2014). However, recent advances in the advent of NGS technologies that enable large amounts of DNA sequence data to be generated in a single sequencing run at low cost, wild plants groups are now also amenable for in-depth genomic analyses. Such studies often address the evolution of polyploid complexes and focus on genome evolution in comparative context (e.g., polyploid and its lower-ploidy parental taxa) (Table 1) (Novák et al., 2010; Dodsworth et al., 2015; WeissSchneeweiss et al., 2015; McCann et al., 2018). These approaches allow for rapid identification of numerous types of DNA repeats providing new chromosomal markers that can be used in molecular cytological analyses applying in situ hybridization (fluorescence and genomic in situ hybridization;
FISH and GISH, respectively) and thus, contributing to better understanding of the evolution of plant genomes (Table 1) (Renny-Byfield et al., 2010; Emadzade et al., 2014; Novák et al., 2014; Zhang et al., 2014; Jang and Weiss-Schneeweiss, 2015). Repetitive DNA fraction of plant genomes is composed of tandem repeats encompassing satellite DNAs, microsatellites and rDNAs (5S and 35S ribosomal RNA genes) as well as dispersed repeats represented by mobile genetic elements, known also as transposable elements. The latter comprise class I retroelements and class II DNA transposons (WeissSchneeweiss et al., 2015). In-depth analyses of repeatomes have recently been demonstrated to be informative for inferences of phylogenetic relationships in plants (Table 1) (Dodsworth et al., 2015, 2017; McCann et al., 2018).

Molecular cytogenetic mapping of the nuclear ribosomal RNA genes encoding for 35S (18S-5.8S-25S) and 5S rDNAs have proved useful for identifying the patterns and dynamics of chromosomal changes in closely related species groups (Jang et al., 2013, 2016a; Vitales et al., 2017). The distribution of rDNA loci has been reported for some Korean monocots, as summarized in Table 1 (data retrieved from Plant rDNA Database; http:// www.plantrdnadatabase.com/, 2018 May 22). The number and localization of rDNA loci in diploids and polyploids was intensively studied in selected genera of Alismatales (Wan et al., 2012), Asparagales (Hizume, 1994; Hizume and Araki, 1994; Lee et al., 1999; Do et al., 1999, 2001; Remon-Büttner et al., 1999; Kim et al., 2004; Hayashi et al., 2005; Lim et al., 2007; Deng et al., 2012; Son et al., 2012), and Liliales (Sultana et al., 2010). A survey of rDNA loci numbers reported for Korean monocots indicated that rDNA loci number can vary at the interspecific level in the genera Allium, Lilium, and Potamogeton (between 2 and 6) (Table 1) regardless of chromosome number and ploidy level variation between species, as show for many other plant groups (Table 1, Appendix 1). The rDNA loci number variation within species or among closely related taxa have often been shown to be correlated with geographic and/or populational factors (e.g., Jang et al., 2016a). Thus, the localization of rDNA loci analyzed in comparative context aids not only the analyses of chromosomal structural changes, but when interpreted in phylogenetic context (e.g., Jang et al., 2013, 2016b), it also allows broader conclusions with implications for taxonomy. Monocot genomes are often more dynamically evolving than those of the dicots. Thus, further cytogenetic analyses of selected groups of Korean monocots will be undertaken to shed light into their genome evolution and evolutionary relationships. Such analyses should and will certainly include also populations and relatives from other geographical areas to allow for more robust conclusions to be drawn. 
Table 1. Summary of the chromosome numbers, ploidy level variation, and numbers of $5 \mathrm{~S}$ and $35 \mathrm{~S}$ rDNA signals in non-Commelinids monocot species occurring in Korea (representing their worldwide distribution)

\begin{tabular}{|c|c|c|c|c|c|}
\hline Taxon & $2 n$ & Ploidy levels & 5S rDNA & $35 \mathrm{~S}$ rDNA & References \\
\hline \multicolumn{6}{|l|}{ Alismatales R. Br. ex Bercht. \& J. Presl } \\
\hline \multirow[t]{2}{*}{ Potamogeton crispus L. } & 48 & $4 x$ & 2 & 2 & Wan et al. (2012) \\
\hline & 52 & $4 x$ & 2 & 2 & Wan et al. (2012) \\
\hline P. distinctus A. Benn. & 52 & $4 x$ & 2 & 2 & Wan et al. (2012) \\
\hline P. malaianus Miq. & 52 & $4 x$ & 2 & 4 & Wan et al. (2012) \\
\hline P. natans L. & 52 & $4 x$ & 4 & 6 & Wan et al. (2012) \\
\hline P. octandrus Poir. & 28 & $2 x$ & 2 & 2 & Wan et al. (2012) \\
\hline \multirow{2}{*}{ P. perfoliatus $\mathrm{L}$. } & 50 & $4 x$ & 2 & 4 & Wan et al. (2012) \\
\hline & 52 & $4 x$ & 2 & 2 & Wan et al. (2012) \\
\hline \multicolumn{6}{|l|}{ Asparagales Link } \\
\hline \multirow[t]{3}{*}{ Allium cepa $\mathrm{L}$. } & 16 & $2 x$ & 4 & 2 & Hizume (1994) \\
\hline & 16 & $2 x$ & 2 & 2 & Do et al. (2001) \\
\hline & 16 & $2 x$ & 4 & 4 & Do et al. (2001) \\
\hline \multirow[t]{3}{*}{ A. fistulosum $\mathrm{L}$. } & 16 & $2 x$ & 2 & 1 & Hizume (1994) \\
\hline & 16 & $2 x$ & 2 & - & Son et al. (2012) \\
\hline & 16 & $2 x$ & 2 & - & Lee et al. (1999) \\
\hline \multirow[t]{2}{*}{ A. sativum $\mathrm{L}$. } & 16 & $2 x$ & 2 & 2 & Son et al. (2012) \\
\hline & 16 & $2 x$ & 6 & 2 & Lee et al. (1999) \\
\hline \multirow[t]{2}{*}{ A. senescens $\mathrm{L}$. } & 16 & $2 x$ & 2 & 2 & Lee et al. (1999) \\
\hline & 32 & $4 x$ & 6 & 2 & Lee et al. (1999) \\
\hline \multirow[t]{2}{*}{ A. tuberosum Rottler ex Spreng. } & 30 & $4 x$ & 8 & 3 & Do et al. (1999) \\
\hline & 32 & $4 x$ & 8 & 4 & Do et al. (1999) \\
\hline Lycoris radiata (L'Hér.) Herb. & 33 & $3 x$ & 4 & 6 & Hayashi et al. (2005) \\
\hline Anemarrhena asphodeloides Bunge & 22 & $2 x$ & 2 & 4 & Kim et al. (2004) \\
\hline \multirow[t]{2}{*}{ Asparagus officinalis $\mathrm{L}$. } & 20 & $2 x$ & 2 & 6 & Remon-Büttner et al. (1999) \\
\hline & 20 & $2 x$ & 8 & 6 & Deng et al. (2012) \\
\hline \multirow[t]{4}{*}{ Scilla scilloides (Lindl.) Druce } & 16 & $2 x$ & - & 2 & Hizume and Araki (1994) \\
\hline & 18 & $2 x$ & - & 2 & Hizume and Araki (1994) \\
\hline & 27 & $3 x$ & - & 2 & Hizume and Araki (1994) \\
\hline & 34 & $4 x$ & - & 4 & Hizume and Araki (1994) \\
\hline Iris setosa Pall. ex Link & 38 & $2 x$ & 4 & 6 & Lim et al. (2007) \\
\hline \multicolumn{6}{|l|}{ Liliales Perleb } \\
\hline Lilium amabile Palib. & 24 & $2 x$ & 2 & 6 & Sultana et al. (2010) \\
\hline L. callosum Siebold \& Zucc. & 24 & $2 x$ & 2 & 10 & Sultana et al. (2010) \\
\hline L. cernuum Kom. & 24 & $2 x$ & 2 & 10 & Sultana et al. (2010) \\
\hline L. concolor Salisb. & 24 & $2 x$ & 2 & 10 & Sultana et al. (2010) \\
\hline L. dauricum K. Gawl. & 24 & $2 x$ & 2 & 8 & Sultana et al. (2010) \\
\hline L. distichum Nakai ex Kamib. & 24 & $2 x$ & 2 & 8 & Sultana et al. (2010) \\
\hline L. hansonii Leichtlin ex D. D. T. Moore & 24 & $2 x$ & 2 & 15 & Sultana et al. (2010) \\
\hline L. lancifolium Thunb. & 24 & $2 x$ & 2 & 10 & Sultana et al. (2010) \\
\hline L. lancifolium Thunb. & 36 & $3 x$ & 3 & 15 & Sultana et al. (2010) \\
\hline L. tsingtauense Gilg & 24 & $2 x$ & 2 & 8 & Sultana et al. (2010) \\
\hline L. tsingtauense Gilg & 24 & $2 x$ & 2 & 8 & Sultana et al. (2010) \\
\hline
\end{tabular}




\section{Acknowledgments}

This work was supported by grants from the National Research Foundation of Korea (NRF) funded by the Korea government (grant numbers NRF-2018R1C1B6003170) to T.S. Jang.

\section{Conflict of Interest}

The authors declare that there are no conflicts of interest.

\section{Literature Cited}

Babcock, E. B. and J. A. Jenkins. 1943. Chromosomes and phylogeny in Crepis. III. The relationships of one hundred and thirteen species. University of California Publications in Botany 18: 241-292.

Bennett, M. D. 1972. Nuclear DNA content and minimum generation time in herbaceous plants. Proceedings of the Royal Society of London Series B-Biological Sciences 181: 109135.

Bennett, M. D. 1998. Plant genome values: how much do we know? Proceedings of the National Academy of Sciences of the United States of America 95: 2011-2016.

Bennett, M. D. and I. J. Leitch. 2012. Angiosperm DNA C-values database (release 8.0, Dec. 2012). Royal Botanic Gardens, Kew.

Blöch, C., H. Weiss-Schneeweiss, G. M. Schneeweiss, M. H. J. Barfuss, C. A. Rebernig, J. L. Villaseñor and T. F. Stuessy. 2009. Molecular phylogenetic analyses of nuclear and plastid DNA sequences support dysploid and polyploid chromosome number changes and reticulate evolution in the diversification of Melampodium (Millerieae, Asteraceae). Molecular Phylogenetics and Evolution 53: 220-233.

Bowers, J. E., B. A. Chapman, J. Rong and A. H. Paterson. 2003. Unraveling angiosperm genome evolution by phylogenetic analysis of chromosomal duplication events. Nature 422: 433438.

Choi, H.-W., J.-S. Kim, S.-H. Lee and J.-W. Bang. 2008. Physical mapping by FISH and GISH of rDNA loci and discrimination of genomes A and B in Scilla scilloides complex distributed in Korea. Journal of Plant Biology 51: 408-412.

Chumová, Z., J. Krejčíková, T. Mandáková, J. Suda and P. Trávníček. 2015. Evolutionary and taxonomic implications of variation in nuclear genome size: lesson from the grass genus Anthoxanthum (Poaceae). PLoS ONE 10: e0133748.

Deng, C.-L., R.-Y. Qin, N.-N. Wang, Y. Cao, J. Gao, W.-J. Gao and L.-D. Lu. 2012. Karyotype of Asparagus by physical mapping of $45 \mathrm{~S}$ and $5 \mathrm{~S}$ rDNA by FISH. Journal of Genetics 91: 209-212.

Do, G.-S., B.-B. Seo, J.-M. Ko, S.-H. Lee, J.-H. Pak, I.-S. Kim and S.-D. Song. 1999. Analysis of somaclonal variation through tissue culture and chromosomal localization of rDNA sites by fluorescent in situ hybridization in wild Allium tuberosum and a regenerated variant. Plant Cell, Tissue and Organ Culture 57: 113-119.

Do, G. S., B. B. Seo, M. Yamamoto, G. Suzuki and Y. Mukai. 2001. Identification and chromosomal location of tandemly repeated DNA sequences in Allium cepa. Genes and Genetic Systems 76: 53-60.

Dodsworth, S., M. W. Chase, L. J. Kelly, I. J. Leitch, J. Macas, P. Novák, M. Piednoël, H. Weiss-Schneeweiss and A. R. Leitch. 2015. Genomic repeat abundances contain phylogenetic signal. Systematic Biology 64: 112-126.

Dodsworth, S., T.-S. Jang, M. Struebig, M. W. Chase, H. WeissSchneeweiss and A. R. Leitch. 2017. Genome-wide repeat dynamics reflect phylogenetic distance in closely related allotetraploid Nicotiana (Solanaceae). Plant Systematics and Evolution 303: 1013-1020.

Emadzade, K., T.-S. Jang, J. Macas, A. Kovařík, P. Novák, J. Parker and H. Weiss-Schneeweiss. 2014. Differential amplification of satellite PaB6 in chromosomally hypervariable Prospero autumnale complex (Hyacinthaceae). Annals of Botany 114: $1597-1608$.

Fleischmann, A., T. P. Michael, F. Rivadavia, A. Sousa, W. Wang, E. M. Temsch, J. Greilhuber, K. F. Müller and G. Heubl. 2014. Evolution of genome size and chromosome number in the carnivorous plant genus Genlisea (Lentibulariaceae), with a new estimate of the minimum genome size in angiosperms. Annals of Botany 114: 1651-1663.

Goldblatt, P. 1980. Polyploidy in angiosperms: monocotyledons. In Polyploidy: Biological Relevance. Lewis, W. H. (ed.), Plenum Press, New York. Pp. 219-239.

Gong, Z., Y. Wu, A. Koblížková, G. A. Torres, K. Wang, M. Iovene, P. Neumann, W. Zhang, P. Novák, C. R. Buell, J. Macas and J. Jiang. 2012. Repeatless and repeat-based centromeres in potato: implications for centromere evolution. The Plant Cell 24: 3559-3574.

Grant, V. 1982. Chromosome number patterns in primitive angiosperms. Botanical Gazette 143: 390-394.

Grant, W. F. 1991. Chromosomal evolution and aneuploidy in Lotus. In Chromosome Engineering in Plant Genetics: Genetics, Breeding, Evolution. Part B. Tsuchiya, T. and P. K. Gupta (eds.), Elsevier, Amsterdam. Pp. 429-447.

Guerra, M. 2008. Chromosome numbers in plant cytotaxonomy: concepts and implications. Cytogenetic and Genome Research 
120: 339-350.

Hayashi, A., T. Saito, T. Mukai, S. Kurita and T. Hori. 2005. Genetic variation in Lycoris radiata var. radiata in Japan. Genes and Genetic Systems 80: 199-212.

Hizume, M. 1994. Allodiploid nature of Allium wakegi Araki revealed by genomic in situ hybridization and localization of 5S and 18S rDNAs. Japanese Journal of Genetics 69: 407415.

Hizume, M. and H. Araki. 1994. Chromosomal localization of rRNA genes in six cytotypes of Scilla scilloides Druce. Cytologia 59: 35-42.

Husband, B. C., S. J. Baldwin and J. Suda. 2013. The incidence of polyploidy in natural plant populations: major patterns and evolutionary processes. In Plant Genome Diversity. Vol. 2. Physical Structure, Behaviour and Evolution of Plant Genomes. Leitch, I. J., J. Greilhuber, J. Doležel and J. F. Wendel (eds.), Springer, Vienna. Pp. 255-276.

Jang, T.-S. 2013. Chromosomal evolution in Prospero autumnale complex. Ph.D. dissertation, University of Vienna, Vienna, Austria, $165 \mathrm{pp}$.

Jang, T.-S., K. Emadzade, J. Parker, E. M. Temsch, A. R. Leitch, F. Speta and H. Weiss-Schneeweiss. 2013. Chromosomal diversification and karyotype evolution of diploids in the cytologically diverse genus Prospero (Hyacinthaceae). BMC Evolutionary Biolology 13: 136.

Jang, T.-S., J. McCann, J. S. Parker, K. Takayama, S.-P. Hong, G. M. Schneeweiss and H. Weiss-Schneeweiss. 2016a. rDNA loci evolution in the genus Glechoma (Lamiaceae). PLoS ONE 11: e0167177.

Jang, T.-S., J. S. Parker, K. Emadzade, E. M. Temsch, A. R. Leitch and H. Weiss-Schneeweiss. 2018. Multiple origins and nested cycles of hybridization result in high tetraploid diversity in the monocot Prospero. Frontiers in Plant Science 9: 433.

Jang, T.-S., J. S. Parker and H. Weiss-Schneeweiss. 2016b. Structural polymorphisms and distinct genomic composition suggest recurrent origin and ongoing evolution of B chromosome in the Prospero autumnale complex (Hyacinthaceae). New Phytologist 210: 669-679.

Jang, T.-S. and H. Weiss-Schneeweiss. 2015. Formamide-free genomic in situ hybridization allows unambiguous discrimination of highly similar parental genomes in diploid hybrids and allopolyploids. Cytogenetic and Genome Research 146: 325331.

Kim, S. Y., H. W. Choi and J. W. Bang. 2004. Physical mapping of rDNAs using McFISH in Anemarrhena asphodeloides Bunge. Korean Journal of Medicinal and Crop Sciences 12: 515-518 (in Korean).

Ko, E.-M., H.-J. Choi and B.-U. Oh. 2009. A cytotaxonomic study of Allium (Alliaceae) sect. Sacculiferum in Korea. Korean Journal of Plant Taxonomy 39: 170-180 (in Korean).

Lee, S. H., G. S. Do and B. B. Seo. 1999. Chromosomal localization of 5S rRNA gene loci and the implications for relationship within the Allium complex. Chromosome Research 7: 89-93.

Leitch, A. R. and I. J. Leitch. 2008. Genome plasticity and the diversity of polyploid plants. Science 320: 481-483.

Leitch, I. J. and A. R. Leitch. 2013. Genome size diversity and evolution in land plants. In Plant Genome Diversity. Vol. 2. Physical Structure, Behaviour and Evolution of Plant Genomes. Leitch, I. J., J. Greilhuber, J. Doležel and J. F. Wendel (eds.), Springer, Vienna. Pp. 307-322.

Levin, D. A. and A. C. Wilson. 1976. Rates of evolution in seed plants: net increase in diversity of chromosome numbers and species numbers through time. Proceedings of the National Academy of Sciences of the United States of America 73: 2086-2090.

Lim, K. Y., R. Matyasek, A. Kovarik and A. Leitch. 2007. Parental origin and genome evolution in the allopolyploid Iris versicolor. Annals of Botany 100: 219-224.

Liu, B. and J. F. Wendel. 2003. Epigenetic phenomena and the evolution of plant allopolyploids. Molecular Phylogenetics and Evolution 29: 365-379.

Mandáková, T., A. Kovařík, J. Zozomová-Lihová, R. ShimizuInatsugi, K. K. Shimizu, K. Mummenhoff, K. Marhold and M. A. Lysak. 2013. The more the merrier: recent hybridization and polyploidy in Cardamine. The Plant Cell 25: 3280-3295.

Mandáková, T., M. Pouch, K. Harmanová, S. H. Zhan, I. Mayrose and M. A. Lysak. 2017. Multispeed genome diploidization and diversification after an ancient allopolyploidization. Molecular Ecology 26: 6445-6462.

Masterson, J. 1994. Stomatal size in fossil plants: evidence for polyploidy in majority of angiosperms. Science 264: 421-424.

Mayrose, I., M. S. Barker and S. P. Otto. 2010. Probabilistic models of chromosome number evolution and the inference of polyploidy. Systematic Biology 59: 132-144.

McCann, J., T.-S. Jang, J. Macas, G. M. Schneeweiss, N. J. Matzke, P. Novák, T. F. Stuessy, J. L. Villaseñor and H. WeissSchneeweiss. 2018. Dating the species network: allopolyploidy and repetitive DNA evolution in American daisies (Melampodium sect. Melampodium, Asteraceae). Systematic Biology 67:1010-1024.

McCann, J., G. M. Schneeweiss, T. F. Stuessy, J. L. Villaseñor and H. Weiss-Schneeweiss. 2016. The impact of reconstruction methods, phylogenetic uncertainty and branch lengths on inference of chromosome number evolution in American daisies (Melampodium, Asteraceae). PLoS ONE 11: e0162299. 
Novák, P., E. Hřibová, P. Neumann, A. Kobližková, J. Doležel and J. Macas. 2014. Genome-wide analysis of repeat diversity across the family Musaceae. PLoS ONE 9: e98918.

Novák, P., P. Neumann and J. Macas. 2010. Graph-based clustering and characterization of repetitive sequences in next-generation sequencing data. BMC Bioinformatics 11: 378.

Osborn, T. C., J. C. Pires, J. A. Birchler, D. L. Auger, Z. J. Chen, H.-S. Lee, L. Comai, A. Madlung, R. W. Doerge, V. Colot and R. A. Martienssen. 2003. Understanding mechanisms of novel gene expression in polyploids. Trends in Genetics 19: 141147.

Otto, S. P. and J. Whitton. 2000. Polyploid incidence and evolution. Annual Review of Genetics 34: 401-437.

Parisod, C., R. Holderegger and C. Brochmann. 2010. Evolutionary consequences of autopolyploidy. New Phytologist 186: 517.

Pellicer, J., M. F. Fay and I. J. Leitch. 2010. The largest eukaryotic genome of them all? Botanical Journal of the Linnean Society 164: 10-15.

Ramsey, J. and D. W. Schemske. 2002. Neopolyploidy in flowering plants. Annual Review of Ecology and Systematics 33: 589-639.

Rapp, R. A. and J. F. Wendel. 2005. Epigenetics and plant evolution. New Phytologist 168: 81-91.

Remon-Büttner, S. M., T. Schmidt and C. Jung. 1999. AFLPs represent highly repetitive sequences in Asparagus officinalis L. Chromosome Research 7: 279-304.

Renny-Byfield, S., M. Ainouche, I. J. Leitch, K. Y. Lim, S. C. Le Comber and A. R. Leitch. 2010. Flow cytometry and GISH reveal mixed ploidy populations and Spartina nonaploids with genomes of $S$. alterniflora and S. maritima origin. Annals of Botany 105: 527-533.

Renny-Byfield, S., A. Kovařík, L. J. Kelly, J. Macas, P. Novák, M. W. Chase, R. A. Nichols, M. R. Pancholi, M.-A. Grandbastien and A. R. Leitch. 2013. Diploidization and genome size change in allopolyploids is associated with differential dynamics of low- and high-copy sequences. The Plant Journal 74: 829-839.

Rice, A., L. Glick, S. Abadi, M. Einhorn, N. M. Kopelman, A. Salman-Minkov, J. Mayzel, O. Chay and I. Mayrose. 2015. The chromosome counts database (CCDB): a community resource of plant chromosome numbers. New Phytologist 206: 19-26.

Roberto, C. 2005. Low chromosome number angiosperms. Caryologia 58: 403-409.

Schubert, I. and M. A. Lysak. 2011. Interpretation of karyotype evolution should consider chromosome structural constraints. Trends in Genetics 27: 207-216.
Soltis, P. S. and D. E. Soltis. 2009. The role of hybridization in plant speciation. Annual Review of Plant Biology 60: 561588.

Soltis, D. E., P. S. Soltis, D. W. Schemske, J. F. Hancock, J. N. Thompson, B. C. Husband and W. S. Judd. 2007. Autopolyploidy in angiosperms: have we grossly underestimated the number of species? Taxon 56: 13-30.

Soltis, D. E., C. J. Visger, D. B. Marchant and P. S. Soltis. 2016. Polyploidy: pitfalls and paths to a paradigm. American Journal of Botany 103: 1146-1166.

Son, J.-H., K.-C. Park, S.-I. Lee, E.-J. Jeon, H.-H. Kim and N.-S. Kim. 2012. Sequence variation and comparison of the $5 \mathrm{~S}$ rRNA sequences in Allium species and their chromosomal distribution in four Allium species. Journal of Plant Biology 55: $15-25$.

Stebbins, G. L. 1971. Chromosomal Evolution in Higher Plants. Edward Arnold, London, 216 pp.

Stuessy, T. F. 1971. Chromosome numbers and phylogeny in Melampodium (Compositae). American Journal of Botany 58: 732-736.

Sultana, S., S.-H. Lee, J.-W. Bang and H.-W. Choi. 2010. Physical mapping of rRNA gene loci and inter-specific relationships in wild Lilium distributed in Korea. Journal of Plant Biology 53: 433-443.

The Angiosperm Phylogeny Group. 2016. An update of the Angiosperm Phylogeny Group classification for the orders and families of flowering plants: APG IV. Botanical Journal of the Linnean Society 181: 1-20.

Uhl, C. H. 1978. Chromosomes of Mexican Sedum II. Section Pachysedum. Rhodora 80: 491-512.

Vanzela, A. L. L., M. Guerra and M. Luceno. 1996. Rhynchospora tenuis Link (Cyperaceae), a species with the lowest number of holocentric chromosomes. Cytobios 88: 219-228.

Vitales, D., U. D’Ambrosio, F. Gálvez, A. Kovařík and S. Garcia. 2017. Third release of the plant rDNA database with updated content and information on telomere composition and sequenced plant genomes. Plant Systematics and Evolution 303: 1115-1121.

Wan, T., X. Zhang, J. Gregan, Y. Zhang, P. Guo and Y. Guo. 2012. A dynamic evolution of chromosome in subgenus Potamogeton revealed by physical mapping of rDNA loci detection. Plant Systematics and Evolution 298: 1195-1210.

Weiss-Schneeweiss, H., K. Emadzade, T.-S. Jang and G. M. Schneeweiss. 2013. Evolutionary consequences, constraints and potential of polyploidy in plants. Cytogenetic and Genome Research 140: 137-150.

Weiss-Schneeweiss, H., A. R. Leitch, J. McCann, T.-S. Jang and J. Macas. 2015. Employing next generation sequencing to 
explore the repeat landscape of the plant genome. In Next Generation Sequencing in Plant Systematics. Regnum Vegetabile. Hörandl, E. and M. Appelhans (eds.), Koeltz Scientific Books, Königstein. Pp. 155-179.

Weiss-Schneeweiss, H. and G. M. Schneeweiss. 2013. Karyotype diversity and evolutionary trends in angiosperms. In Plant Genome Diversity. Vol. 2. Physical Structure, Behaviour and Evolution of Plant Genomes. Leitch, I. J., J. Greilhuber, J. Doležel and J. F. Wendel (eds.), Springer, Vienna. Pp. 209230.
Weiss-Schneeweiss, H., T. F. Stuessy and J. L. Villaseñor. 2009. Chromosome numbers, karyotypes, and evolution in Melampodium (Asteraceae). International Journal of Plant Sciences 170: 1168-1182.

Zhang, H., A. Kobližková, K. Wang, Z. Gong, L. Oliveira, G. A. Torres, Y. Wu, W. Zhang, P. Novák, C. R. Buell, J. Macas and J. Jiang. 2014. Boom-bust turnovers of megabase-sized centromeric DNA in Solanum species: rapid evolution of DNA sequences associated with centromeres. The Plant Cell 26: $1436-1447$. 
Appendix 1. Information on base chromosome number, ploidy level (if known), and genome size data with emphasis on non-Commelinids monocot species occurring in Korea (representing their worldwide distribution

\begin{tabular}{|c|c|c|c|c|c|}
\hline Order/Family/Genus/Species & Chromosome number $(2 n)$ & $\begin{array}{l}\text { Base chromosome } \\
\text { number }(x)\end{array}$ & Ploidy levels & $2 \mathrm{C}$-value (pg) & Korean name \\
\hline \multicolumn{6}{|l|}{ Acorales Mart. } \\
\hline \multicolumn{6}{|l|}{ Acoraceae Martinov } \\
\hline Acorus calamus L. & $18,24,36,44,45,48,66$ & $x=9,11,12$ & $2 x, 4 x, 5 x, 6 x$ & 1.3 & 창포 \\
\hline A. gramineus Aiton & $18,22,24$ & $x=9,11,12$ & $2 x$ & 0.8 & 석창포 \\
\hline \multicolumn{6}{|l|}{ Alismatales R. Br. ex Bercht. \& J. Presl } \\
\hline \multicolumn{6}{|l|}{ Araceae Juss. } \\
\hline Arisaema amurense Maxim. & $26,28,39,48,52,56,70$ & $x=13,14$ & $2 x, 3 x, 4 x, 5 x$ & - & 둥근잎천남성 \\
\hline A. heterophyllum Blume & $28,56,84,140,168$ & $x=13,14$ & $2 x, 4 x, 10 x, 12 x$ & - & 두루미천남성 \\
\hline A. negishii Makino & 28 & $x=14$ & $2 x$ & - & 섬천남성 \\
\hline A. peninsulae Nakai & 26,28 & $x=13,14$ & $2 x$ & - & 점박이천남성 \\
\hline A. ringens (Thunb.) Schott & 28 & $x=14$ & $2 x$ & - & 큰천남성 \\
\hline A. thunbergii Blume & 28 & $x=14$ & $2 x$ & - & 무늬천남성 \\
\hline Calla palustris $\mathrm{L}$. & $36,60,72$ & $x=18$ & $2 x, 3 x, 4 x$ & 2.1 & 산부채 \\
\hline Lemna perpusilla Torr. & $20,40,50,60,70,72,84$ & $x=10$ & $2 x, 4 x, 5 x, 6 x, 7 x, 8 x$ & 0.8 & 좀개구리밥 \\
\hline Pinellia ternata (Thunb.) Breitenb. & $\begin{array}{c}26,42,54,72,78,90,91,99,104 \\
108,115,117\end{array}$ & $x=13$ & $\begin{array}{c}2 x, 3 x, 4 x, 5 x, 6 x, 7 x \\
8 x, 9 x\end{array}$ & 7.0 & 반하 \\
\hline P. tripartita (Blume) Schott & 26,52 & $x=13$ & $2 x, 4 x$ & - & 대반하 \\
\hline Spirodela polyrrhiza (L.) Schleid. & $30,32,38,40,50,80$ & Unknown & Unknown & 0.6 & 개구리밥 \\
\hline Symplocarpus nipponicus Makino & 30 & $x=15$ & $2 x$ & - & 애기앉은부채 \\
\hline S. renifolius Schott ex Tzvelev & 60 & $x=15$ & $4 x$ & - & 앉은부채 \\
\hline \multicolumn{6}{|l|}{ Tofieldiaceae Takht. } \\
\hline Tofieldia coccinea Richardson & 30,32 & $x=15,16$ & $2 x$ & - & 숙은돌창포 \\
\hline \multicolumn{6}{|l|}{ Alismataceae Vent. } \\
\hline Alisma canaliculatum A. Braun \& C. D. Bouché & $26,28,40,42$ & $x=13,14$ & $2 x, 3 x$ & - & 택사 \\
\hline A. plantago-aquatica subsp. orientale (Sam.) Sam. & 14,28 & $x=7$ & $2 x, 4 x$ & - & 질경이택사 \\
\hline Sagittaria aginashii Makino & 22 & $x=11$ & $2 x$ & - & 보풀 \\
\hline S. natans Pall. & 22 & $x=11$ & $2 x$ & - & 대택소귀나물 \\
\hline S. pygmaea Miq. & 22 & $x=11$ & $2 x$ & - & 올미 \\
\hline S. trifolia $\mathrm{L}$. & 22 & $x=11$ & $2 x$ & - & 벗풀 \\
\hline \multicolumn{6}{|l|}{ Hydrocharitaceae Juss. } \\
\hline Blyxa aubertii Rich. & $24,32,40$ & $x=8,12$ & $2 x, 4 x, 5 x$ & - & 올챙이자리 \\
\hline B. japonica (Miq.) Maxim. ex Asch. \& Gürke & 72 & $x=12$ & $6 x$ & - & 올챙이솔 \\
\hline Hydrilla verticillata (L.) Royle & $16,24,32$ & $x=8$ & $2 x, 3 x, 4 x$ & - & 검정말 \\
\hline Najas graminea Delile & $12,24,36,48,72$ & $x=6$ & $2 x, 4 x, 6 x, 8 x, 12 x$ & - & 나자스말 \\
\hline N. marina $\mathrm{L}$. & $12,24,48,60$ & $x=6$ & $2 x, 4 x, 8 x, 10 x$ & - & 민나자스말 \\
\hline
\end{tabular}


Appendix 1. Continued.

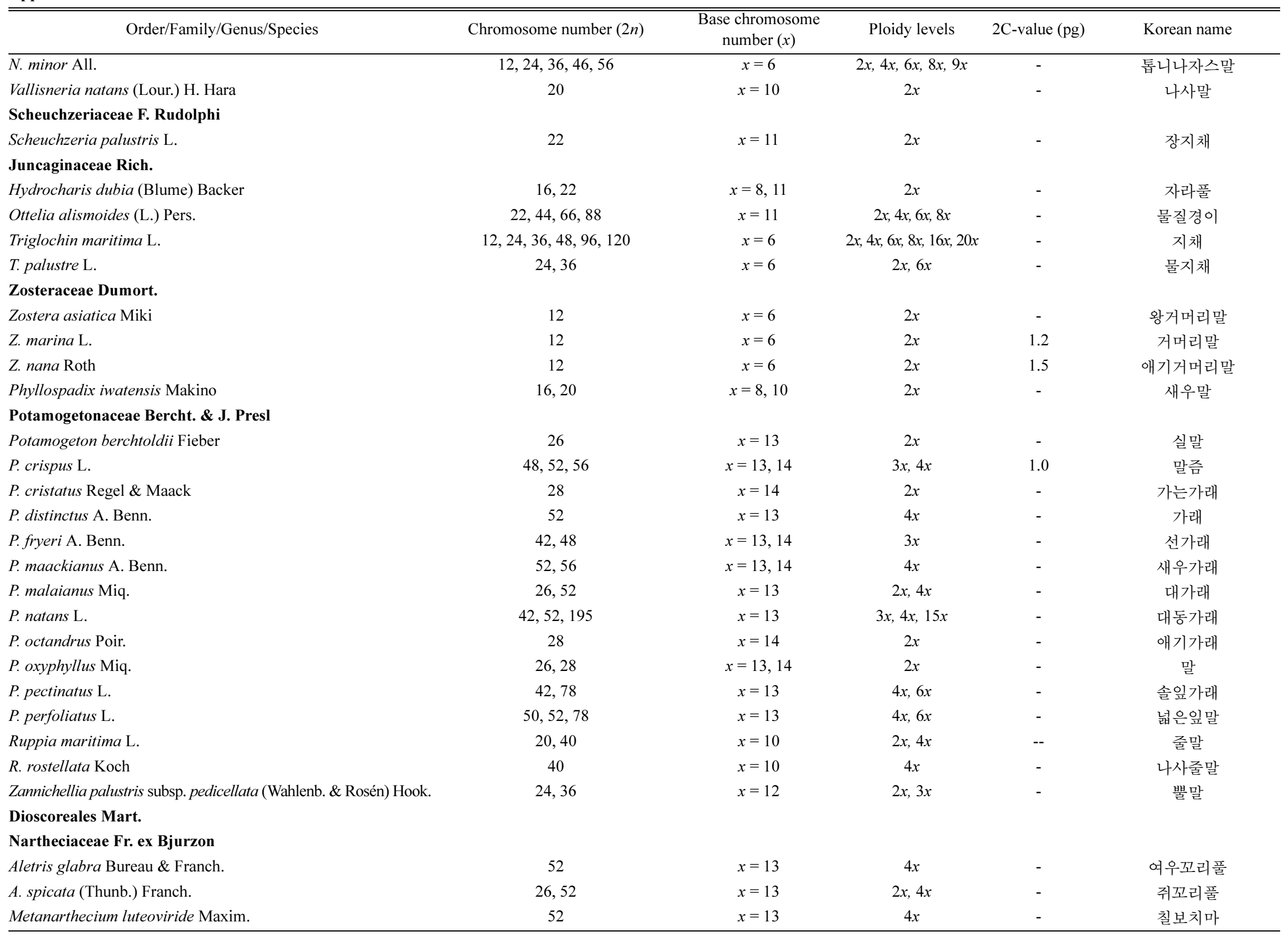




\begin{tabular}{|c|c|c|c|c|c|}
\hline Order/Family/Genus/Species & Chromosome number $(2 n)$ & $\begin{array}{c}\text { Base chromosome } \\
\text { number }(x)\end{array}$ & Ploidy levels & 2C-value (pg) & Korean name \\
\hline \multicolumn{6}{|l|}{ Dioscoreaceae R. Br. } \\
\hline Dioscorea batatas Decne. & 140 & $x=10$ & $14 x$ & - & 마 \\
\hline D. bulbifera $\mathrm{L}$. & $40,60,80$ & $x=10$ & $2 x, 4 x, 6 x$ & 2.4 & 둥근마 \\
\hline D. japonica Thunb. & 100,400 & $x=10$ & $10 x, 40 x$ & - & 참마 \\
\hline D. nipponica Makino & 20,40 & $x=10$ & $2 x, 4 x$ & - & 부채마 \\
\hline D. septemloba Thunb. & 20,40 & $x=10$ & $2 x, 4 x$ & - & 국화마 \\
\hline D. tenuipes Franch. \& Sav. & 20,40 & $x=10$ & $2 x, 4 x$ & - & 각시마 \\
\hline D. tokoro Makino ex Miyabe & 20 & $x=10$ & $2 x$ & 0.8 & 도꼬로마 \\
\hline \multicolumn{6}{|l|}{ Liliales Perleb } \\
\hline \multicolumn{6}{|l|}{ Melanthiaceae Batsch ex Borkh. } \\
\hline Chionographis japonica (Willd.) Maxim. & 24,42 & $x=12$ & $2 x, 4 x$ & - & 실꽃풀 \\
\hline Heloniopsis orientalis (Thunb.) Tanaka & 34 & $x=17$ & $2 x$ & 5.3 & 처녀치마 \\
\hline Paris verticillata $\mathrm{M}$. Bieb. & $10,15,20$ & $x=5$ & $2 x, 3 x, 4 x$ & - & 삿갓나물 \\
\hline Trillium kamtschaticum Pall. ex Pursh & 10,30 & $x=5$ & $2 x, 6 x$ & 89.0 & 연영초 \\
\hline T. tschonoskii Maxim. & 10,20 & $x=5$ & $2 x, 4 x$ & - & 큰연영초 \\
\hline Veratrum bohnhofii var. latifolium Nakai & 16,32 & $x=8$ & $2 x, 4 x$ & - & 삼수여로 \\
\hline V. dolichopetalum O. Loes. & 32 & $x=8$ & $4 x$ & - & 푸른박새 \\
\hline V. maackii Regel & 16 & $x=8$ & $2 x$ & - & 긴잎여로 \\
\hline V. maackii var. parviflorum (Maxim.) H. Hara & 16,32 & $x=8$ & $2 x, 4 x$ & - & 파란여로 \\
\hline V. nigrum var. ussuriense Lose. $\mathrm{f}$. & 16 & $x=8$ & $2 x$ & - & 참여로 \\
\hline V. oxysepalum Turcz. & $32,64,80$ & $x=8$ & $4 x, 8 x, 10 x$ & - & 박새 \\
\hline V. versicolor Nakai & 16 & $x=8$ & $2 x$ & - & 흰여로 \\
\hline Zygadenus sibiricus (L.) A. Gray & 32 & $x=8$ & $4 x$ & - & 나도여로 \\
\hline \multicolumn{6}{|l|}{ Colchiaceae DC. } \\
\hline Disporum sessile (Thunb.) D. Don ex Schult. \& Schult. & 16,24 & $x=8$ & $2 x, 3 x$ & 37.2 & 윤판나물 \\
\hline D. smilacinum A. Gray & 16 & $x=8$ & $2 x$ & - & 애기나리 \\
\hline D. viridescens (Maxim.) Nakai & 16,17 & $x=8$ & $2 x$ & - & 큰애기나리 \\
\hline \multicolumn{6}{|l|}{ Smilacaceae Vent. } \\
\hline Smilax china $\mathrm{L}$. & $32,64,96$ & $x=16$ & $2 x, 4 x, 6 x$ & - & 청미래덩굴 \\
\hline S. nipponica Miq. & 32 & $x=16$ & $2 x$ & - & 선밀나물 \\
\hline S. riparia var. ussuriensis (Regel) Hara \& T. Koyama & 32 & $x=16$ & $2 x$ & - & 밀나물 \\
\hline S. sieboldii Miq. & 32 & $x=16$ & $2 x$ & - & 청가시덩굴 \\
\hline \multicolumn{6}{|l|}{ Liliaceae Juss. } \\
\hline Clintonia udensis Trautv. \& C. A. Mey. & $14,28,38$ & $x=7$ & $2 x, 4 x, 5 x$ & - & 나도옥잠화 \\
\hline Erythronium japonicum (Balrer) Decne. & 24 & $x=12$ & $2 x$ & - & 얼레지 \\
\hline Fritillaria usuriensis Maxim. & 22,24 & $x=11,12$ & $2 x$ & - & 패모 \\
\hline
\end{tabular}


Appendix 1. Continued.

\begin{tabular}{|c|c|c|c|c|c|}
\hline Order/Family/Genus/Species & Chromosome number $(2 n)$ & $\begin{array}{c}\text { Base chromosome } \\
\text { number }(x)\end{array}$ & Ploidy levels & $2 \mathrm{C}$-value (pg) & Korean name \\
\hline Gagea lutea (L.) K. Gawl. & $36,48,72,96,132$ & $x=16,18$ & $2 x, 3 x, 4 x, 6 x, 8 x$ & 39.5 & 중의무릇 \\
\hline Lilium amabile Palib. & 24 & $x=12$ & $2 x$ & 27.4 & 털중나리 \\
\hline L. callosum Siebold \& Zucc. & 24 & $x=12$ & $2 x$ & - & 땅나리 \\
\hline L. cernuum Kom. & 24 & $x=12$ & $2 x$ & - & 솔나리 \\
\hline L. concolor Salisb. & 24 & $x=12$ & $2 x$ & - & 하늘나리 \\
\hline L. dauricum K. Gawl. & 24 & $x=12$ & $2 x$ & - & 날개하늘나리 \\
\hline L. distichum Nakai ex Kamib. & 24 & $x=12$ & $2 x$ & - & 말나리 \\
\hline L. hansonii Leichtlin ex D. D. T. Moore & 24 & $x=12$ & $2 x$ & - & 섬 말나리 \\
\hline L. lancifolium Thunb. & 24,36 & $x=12$ & $2 x, 3 x$ & - & 참나리 \\
\hline L. leichtlinii var. maximowiczii (Regel) Baker & 26 & $x=12$ & $2 x$ & - & 중나리 \\
\hline L. tenuifolium Fisch. & 24 & $x=12$ & $2 x$ & - & 큰솔나리 \\
\hline L. tsingtauense Gilg & 24 & $x=12$ & $2 x$ & - & 하늘말나리 \\
\hline Lloydia serotina (L.) Rchb. & 24 & $x=12$ & $2 x$ & - & 개감채 \\
\hline L. triflora (Ledeb.) Baker & 24 & $x=12$ & $2 x$ & - & 나도개감채 \\
\hline Streptopus amplexifolius (L.) DC. & 16,32 & $x=8$ & $2 x, 4 x$ & 13.0 & 죽대아재비 \\
\hline S. ovalis (Ohwi) F. T. Wang \& Y. C. Tang & 16 & $x=8$ & $2 x$ & - & 진부애기나리 \\
\hline Tricyrtis macropoda Miq. & 26 & $x=13$ & $2 x$ & 8.5 & 빼꾹나리 \\
\hline Tulipa edulis (Miq.) Baker & 24 & $x=12$ & $2 x$ & - & 산자고 \\
\hline T. heterophylla (Regel) Baker & 24 & $x=12$ & $2 x$ & 37.5 & 금대산자고 \\
\hline \multicolumn{6}{|l|}{ Asparagales Link } \\
\hline \multicolumn{6}{|l|}{ Orchidaceae Juss. } \\
\hline Amitostigma gracile (Blume) Schltr. & 42 & $x=21$ & $2 x$ & - & 병아리난초 \\
\hline Bletilla striata (Thunb.) Rchb. & 32,76 & $x=16,19$ & $2 x, 4 x$ & 5.9 & 자란 \\
\hline Bulbophyllum drymoglossum Maxim. & 40 & $x=20$ & $2 x$ & - & 콩짜개난 \\
\hline B. inconspicuum Maxim. & 38 & $x=19$ & $2 x$ & - & 혹난초 \\
\hline Calanthe discolor Lindl. & 40 & $x=20$ & $2 x$ & - & 새우난초 \\
\hline C. reflexa Maxim. & 40 & $x=20$ & $2 x$ & - & 여름새우난 \\
\hline C. striata $\mathrm{R}$. Br. ex Lindl. & 40 & $x=20$ & $2 x$ & - & 금새우난 \\
\hline Calypso bulbosa (L.) Oakes & 28 & $x=14$ & $2 x$ & - & 풍선난초 \\
\hline Cephalanthera erecta (Thunb.) Blume & 34 & $x=17$ & $2 x$ & - & 은난초 \\
\hline C. falcata (Thunb.) Blume & 34 & $x=17$ & $2 x$ & - & 금난초 \\
\hline Corallorhiza trifida Châtel. & 42 & $x=21$ & $2 x$ & - & 산호란 \\
\hline
\end{tabular}




\begin{tabular}{|c|c|c|c|c|c|}
\hline Order/Family/Genus/Species & Chromosome number $(2 n)$ & $\begin{array}{c}\text { Base chromosome } \\
\text { number }(x)\end{array}$ & Ploidy levels & $2 \mathrm{C}$-value (pg) & Korean name \\
\hline Cremastra appendiculata (D. Don) Makino & 48 & $x=24$ & $2 x$ & - & 약난초 \\
\hline C. unguiculata (Finet) Finet & 48 & $x=24$ & $2 x$ & - & 두잎약난초 \\
\hline Cymbidium goeringii (Rchb.) Rchb. & 40 & $x=20$ & $2 x$ & - & 보춘화 \\
\hline C. kanran Makino & 40 & $x=20$ & $2 x$ & - & 한란 \\
\hline C. macrorhizon Lindl. & 38 & $x=19$ & $2 x$ & - & 대흥란 \\
\hline Cypripedium calceolus $\mathrm{L}$. & 20 & $x=10$ & $2 x$ & 64.7 & 노랑복주머니란 \\
\hline C. guttatum var. koreanum Nakai & 20 & $x=10$ & $2 x$ & - & 털복주머니란 \\
\hline C. japonicum Thunb. & 20 & $x=10$ & $2 x$ & 64.0 & 광릉요강꽃 \\
\hline C. macranthos Sw. & $20,21,22$ & $x=10$ & $2 x$ & 74.8 & 복주머니란 \\
\hline Dendrobium moniliforme (L.) Sw. & 38,57 & $x=19$ & $2 x, 3 x$ & - & 석곡 \\
\hline Epipactis papillosa Franch. \& Sav. & 40 & $x=20$ & $2 x$ & - & 청닭의난초 \\
\hline E. thunbergii A. Gray & 40 & $x=20$ & $2 x$ & - & 닭의난초 \\
\hline Epipogium aphyllum $\mathrm{Sw}$. & 68 & $x=17$ & $4 x$ & - & 유령란 \\
\hline Galeola septentrionalis Rchb. & 28 & $x=14$ & $2 x$ & - & 으름난초 \\
\hline Gastrodia elata Blume & 36 & $x=18$ & $2 x$ & - & 천마 \\
\hline Goodyera macrantha Maxim. & 30 & $x=15$ & $2 x$ & - & 붉은사철란 \\
\hline G. maximowicziana Makino & 28,56 & $x=14$ & $2 x, 4 x$ & - & 섬사철란 \\
\hline G. repens (L.) R. Br. & 30 & $x=15$ & $2 x$ & 9.7 & 애기사철란 \\
\hline G. schlechtendaliana Rchb. & 30 & $x=15$ & $2 x$ & - & 사철란 \\
\hline G. velutina Maxim. ex Regel & 30 & $x=15$ & $2 x$ & - & 털사철란 \\
\hline Gymnadenia conopsea (L.) R. Br. & $40,80,100$ & $x=20$ & $2 x, 4 x, 5 x$ & 11.0 & 손바닥난초 \\
\hline Habenaria flagellifera Makino & $42,46,88$ & $x=21,22,23$ & $2 x, 4 x$ & - & 방울난초 \\
\hline H. linearifolia Maxim. & 28 & $x=14$ & $2 x$ & - & 잠자리난초 \\
\hline H. radiata (Thunb.) Spreng. & 32,64 & $x=16$ & $2 x, 4 x$ & - & 해오라비난초 \\
\hline Herminium lanceum var. longicrure (C. Wright) H. Hara & 38,76 & $x=19$ & $2 x, 4 x$ & - & 씨눈난초 \\
\hline H. monorchis (L.) R. Br. & 38,40 & $x=19,20$ & $2 x$ & - & 나도씨눈난 \\
\hline Hetaeria sikokiana (Makino \& F. Maek.) Tuyama & 42 & $x=21$ & $2 x$ & - & 애기천마 \\
\hline Lecanorchis japonica Blume & 36 & $x=18$ & $2 x$ & - & 무엽란 \\
\hline Liparis japonica (Miq.) Maxim. & 30 & $x=15$ & $2 x$ & - & 키다리난초 \\
\hline L. koreana (Nakai) Nakai & 30 & $x=15$ & $2 x$ & - & 참나리난초 \\
\hline L. krameri Franch. \& Sav. & 30 & $x=15$ & $2 x$ & - & 나나벌이난초 \\
\hline L. kumokiri F. Maek. & 26,30 & $x=13,15$ & $2 x$ & - & 옥잠난초 \\
\hline L. makinoana Schltr. & 30 & $x=15$ & $2 x$ & - & 나리난초 \\
\hline Listera nipponica Makino & 38 & $x=19$ & $2 x$ & - & 털쌍잎난초 \\
\hline L. pinetorum Lindl. & 40 & $x=20$ & $2 x$ & - & 쌍잎난초 \\
\hline Microstylis monophyllos (L.) Lindl. & 30 & $x=15$ & $2 x$ & - & 이삭단엽란 \\
\hline
\end{tabular}


Appendix 1. Continued.

\begin{tabular}{|c|c|c|c|c|c|}
\hline Order/Family/Genus/Species & Chromosome number $(2 n)$ & $\begin{array}{c}\text { Base chromosome } \\
\text { number }(x)\end{array}$ & Ploidy levels & 2C-value (pg) & Korean name \\
\hline Myrmechis japonica (Rchb.) Rolfe & 56 & $x=14$ & $4 x$ & - & 개미난초 \\
\hline Neofinetia falcata (Thunb.) Hu & 38 & $x=19$ & $2 x$ & 4.7 & 풍란 \\
\hline Neottia acuminata Schltr. & 18 & $x=9$ & $2 x$ & - & 애기무엽란 \\
\hline N. nidus-avis var. manshurica Kom. & 36 & $x=9$ & $4 x$ & - & 새둥지란 \\
\hline Oberonia japonica (Maxim.) Makino & 30 & $x=15$ & $2 x$ & - & 차걸이난 \\
\hline Orchis cyclochila (Franch. \& Sav.) Maxim. & 42 & $x=21$ & $2 x$ & - & 나도제비란 \\
\hline O. graminifolia (Rchb.) Tang \& F. T. Wang & 42 & $x=21$ & $2 x$ & - & 나비난초 \\
\hline O. jooiokiana Makino & 42 & $x=21$ & $2 x$ & - & 너도제비난 \\
\hline Oreorchis patens (Lindl.) Lindl. & 48 & $x=24$ & $2 x$ & - & 감자난 \\
\hline Platanthera hologlottis Maxim. & 42 & $x=21$ & $2 x$ & - & 흰제비난 \\
\hline P. japonica (Thunb.) Lindl. & 42 & $x=21$ & $2 x$ & - & 갈매기난초 \\
\hline P. mandarinorum Rchb. & 42 & $x=21$ & $2 x$ & - & 산제비난 \\
\hline P. minor (Miq.) Rchb. & 42 & $x=21$ & $2 x$ & - & 한라잠자리난 \\
\hline P. ophrydioides F. Schmidt & 42 & $x=21$ & $2 x$ & - & 구름제비난 \\
\hline P. sachalinensis F. Schmidt & 42 & $x=21$ & $2 x$ & - & 큰제비난 \\
\hline Pogonia japonica Rchb. & 20 & $x=10$ & $2 x$ & - & 큰방울새난 \\
\hline P. minor (Makino) Makino & 18 & $x=9$ & $2 x$ & - & 방울새난 \\
\hline Sedirea japonica (Rchb. f.) Garay \& Sweet & 38 & $x=19$ & $2 x$ & - & 나도풍란 \\
\hline Spiranthes sinensis (Pers.) Ames & 30 & $x=15$ & $2 x$ & - & 타래난초 \\
\hline Taeniophyllum glandulosum Blume & 38 & $x=19$ & $2 x$ & - & 거미난 \\
\hline Tipularia ussuriensis (Regel) H. Hara & 42 & $x=21$ & $2 x$ & - & 나도잠자리난 \\
\hline Vexillabium yakushimense (Yamam.) F. Maek. & 26 & $x=13$ & $2 x$ & - & 백운란 \\
\hline \multicolumn{6}{|l|}{ Iridaceae Juss. } \\
\hline Belamcanda chinensis (L.) DC. & 32 & $x=16$ & $2 x$ & - & 범부채 \\
\hline Iris dichotoma Pall. & 34 & $x=17$ & $2 x$ & - & 대청부채 \\
\hline I. ensata var. spontanea (Makino) Nakai & 24 & $x=12$ & $2 x$ & - & 꽃창포 \\
\hline I. koreana Nakai & 50 & $x=25$ & $2 x$ & - & 노랑붓꽃 \\
\hline I. lactea var. chinensis (Fisch.) Koidz. & 32,40 & $x=16,20$ & $2 x$ & - & 타래붓꽃 \\
\hline I. laevigata Fisch. & $28,32,34$ & $x=14,16,17$ & $2 x$ & - & 제비붓꽃 \\
\hline I. minutoaurea Makino & 22 & $x=11$ & $2 x$ & - & 금붓꽃 \\
\hline I. rossii Baker & 32 & $x=16$ & $2 x$ & - & 각시붓꽃 \\
\hline I. ruthenica K. Gawl. & $32,40,84$ & $x=16,20,21$ & $2 x, 4 x$ & - & 솔붓꽃 \\
\hline I. sanguinea Donn ex Hornem. & 26,28 & $x=13,14$ & $2 x$ & - & 붓꽃 \\
\hline I. setosa Pall. ex Link & 40 & $x=20$ & $2 x$ & - & 부채붓꽃 \\
\hline I. uniflora var. caricina Kitag. & 42 & $x=21$ & $2 x$ & - & 난장이붓꽃 \\
\hline
\end{tabular}




\begin{tabular}{|c|c|c|c|c|c|}
\hline Order/Family/Genus/Species & Chromosome number $(2 n)$ & $\begin{array}{c}\text { Base chromosome } \\
\text { number }(x)\end{array}$ & Ploidy levels & 2C-value (pg) & Korean name \\
\hline \multicolumn{6}{|l|}{ Asphodelaceae Juss. } \\
\hline Hemerocallis dumortieri E. Morren & 22 & $x=11$ & $2 x$ & - & 각시원추리 \\
\hline H. fulva (L.) L. & 22,33 & $x=11$ & $2 x, 3 x$ & - & 원추리 \\
\hline H. lilioasphodelus L. & 22 & $x=11$ & $2 x$ & - & 골잎원추리 \\
\hline H. littorea Makino & 22 & $x=11$ & $2 x$ & - & 홍도원추리 \\
\hline H. middendorffii Trautv. \& C. A. Mey. & 22 & $x=11$ & $2 x$ & - & 큰원추리 \\
\hline H. minor Mill. & 22 & $x=11$ & $2 x$ & - & 애기원추리 \\
\hline H. thunbergii Barr & 22 & $x=11$ & $2 x$ & - & 노랑원추리 \\
\hline \multicolumn{6}{|l|}{ Amaryllidaceae J. St.-Hil. } \\
\hline Allium condensatum Turcz. & 16 & $x=8$ & $2 x$ & - & 노랑부추 \\
\hline A. longistylum Baker & 16 & $x=8$ & $2 x$ & - & 강부추 \\
\hline A. linearifolium H. J. Choi \& B. U. Oh & 16 & $x=8$ & $2 x$ & - & 선부추 \\
\hline A. macrostemon Bunge & $32,40,48$ & $x=8$ & $4 x, 5 x, 6 x$ & 43.2 & 산달래 \\
\hline A. maximowiczii Regel & 16 & $x=8$ & $2 x$ & - & 산파 \\
\hline A. microdictyon Prokh. & 16 & $x=8$ & $2 x$ & - & 산마늘 \\
\hline A. monanthum Maxim. & $16,24,32$ & $x=8$ & $2 x, 3 x, 4 x$ & - & 달래 \\
\hline A. ochotense Prokh. & 16,32 & $x=8$ & $2 x, 4 x$ & - & 울릉산마늘 \\
\hline A. sacculiferum Maxim. & $16,32,42$ & $x=8$ & $2 x, 4 x, 5 x$ & - & 참산부추 \\
\hline A. senescens $\mathrm{L}$. & 16,32 & $x=8$ & $2 x, 4 x$ & - & 두메부추 \\
\hline A. taquetii H. Lév. \& Vaniot & 16 & $x=8$ & $2 x$ & - & 한라부추 \\
\hline A. thunbergii G. Don & 16,32 & $x=8$ & $2 x, 4 x$ & - & 산부추 \\
\hline $\begin{array}{l}\text { A. thunbergii var. deltoides (S.Yu, W. Lee \& S. Lee) H. J. Choi } \\
\text { \& B. U. Oh }\end{array}$ & 16 & $x=8$ & $2 x$ & & 세모산부추 \\
\hline A. thunbergii var. teretifolium H. J. Choi \& B. U. Oh & 16 & $x=8$ & $2 x$ & & 둥근산부추 \\
\hline Crinum asiaticum var. japonicum Baker & 22 & $x=11$ & $2 x$ & - & 문주란 \\
\hline Lycoris albiflora Koidz. & $17,18,19$ & $x=9$ & $2 x$ & - & 흰상사화 \\
\hline L. radiata (L'Hér.) Herb. & 33 & $x=11$ & $3 x$ & - & 석산 \\
\hline L. sanguinea var. koreana (Nakai) T. Koyama & $21,22,33,45$ & $x=11$ & $2 x, 3 x, 4 x$ & - & 백양꽃 \\
\hline \multicolumn{6}{|l|}{ Asparagaceae Juss. } \\
\hline Anemarrhena asphodeloides Bunge & 22 & $x=11$ & $2 x$ & 5.7 & 지모 \\
\hline Asparagus cochinchinensis (Lour.) Merr. & 20 & $x=10$ & $2 x$ & - & 천문동 \\
\hline A. oligoclonos Maxim. & 20,40 & $x=10$ & $2 x, 4 x$ & - & 방울비짜루 \\
\hline A. schoberioides Kunth & 20,40 & $x=10$ & $2 x, 4 x$ & - & 비짜루 \\
\hline Convallaria keiskei Miq. & 38 & $x=19$ & $2 x$ & - & 은방울꽃 \\
\hline Hosta capitata (Koidz.) Nakai & 60 & $x=30$ & $2 x, 3 x$ & 19.3 & 일월비비추 \\
\hline H. clausa Nakai & $60,90,96$ & $x=30$ & $2 x, 3 x$ & 28.5 & 참비비추 \\
\hline
\end{tabular}




\begin{tabular}{|c|c|c|c|c|c|}
\hline Order/Family/Genus/Species & Chromosome number $(2 n)$ & $\begin{array}{c}\text { Base chromosome } \\
\text { number }(x)\end{array}$ & Ploidy levels & 2C-value (pg) & Korean name \\
\hline H. clausa var. normalis F. Maek. & $48,60,90$ & $x=30$ & $2 x, 3 x$ & 19.3 & 주걱비비추 \\
\hline H. longipes (Franch. \& Sav.) Matsum. & 60 & $x=30$ & $2 x$ & 26.3 & 비비추 \\
\hline H. longissima F. Maek. & 60 & $x=30$ & $2 x$ & 19.3 & 산옥잠화 \\
\hline H. minor (Baker) Nakai & 60 & $x=30$ & $2 x$ & - & 좀비비추 \\
\hline Liriope platyphylla F. T. Wang \& T. Tang & $36,72,108,112$ & $x=18$ & $2 x, 4 x, 6 x$ & 21.1 & 맥문동 \\
\hline L. spicata Lour. & $36,72,108$ & $x=18$ & $2 x, 4 x, 6 x$ & 25.6 & 개맥문동 \\
\hline Maianthemum bifolium (L.) F. W. Schmidt & 36,54 & $x=18$ & $2 x, 3 x$ & 30.6 & 두루미꽃 \\
\hline Ophiopogon jaburan (Siebold) Lodd. & 36 & $x=18$ & $2 x$ & - & 맥문아재비 \\
\hline O. japonicus (Thunb.) K. Gawl. & $36,67,68,70,72$ & $x=18$ & $2 x, 4 x$ & 21.6 & 소엽맥문동 \\
\hline Polygonatum falcatum A. Gray & 18,20 & $x=9,10$ & $2 x$ & - & 진황정 \\
\hline P. humile Fisch. ex Maxim. & $20,22,30$ & $x=10,11$ & $2 x, 3 x$ & - & 각시둥굴레 \\
\hline P. inflatum Kom. & 22 & $x=11$ & $2 x$ & - & 퉁둥굴레 \\
\hline P. involucratum (Franch. \& Sav.) Maxim. & $18,20,22$ & $x=9,10,11$ & $2 x$ & - & 용둥굴레 \\
\hline P. lasianthum Maxim. & 20 & $x=10$ & $2 x$ & - & 죽대 \\
\hline P. odoratum var. pluriflorum (Miq.) Ohwi & 20,30 & $x=10$ & $2 x, 3 x$ & - & 둥굴레 \\
\hline Scilla scilloides (Lind1.) Druce & $16,18,26,27,34,36,38,44,53,70$ & $x=8,9$ & $2 x, 3 x, 4 x, 5 x, 6 x$ & - & 무릇 \\
\hline Smilacina dahurica Turcz. ex Fisch. \& C. A. Mey. & 36 & $x=18$ & $2 x$ & - & 민솜대 \\
\hline S. japonica A. Gary & 36 & $x=18$ & $2 x$ & - & 풀솜대 \\
\hline S. trifolium (L.) Desf. & 36 & $x=18$ & $2 x$ & 22.2 & 세잎솜대 \\
\hline
\end{tabular}

The table is arranged alphabetically by order, family, and genus recognized by APG IV classification system (The Angiosperm Phylogeny Group, 2016). Note: All chromosome number information was taken from Rice et al. (2015). 